\title{
Metabolic syndrome among type 2 diabetic patients in Ethiopia: a cross-sectional study

Mequanent Kassa Birarra ${ }^{*^{*}}$ (1) and Dessalegn Asmelashe Gelayee ${ }^{2}$

\begin{abstract}
Background: Metabolic syndrome (MetS) increases risk of cardiovascular diseases (CVD), premature death as well as cost related to health care.This study was aimed at investigating the prevalence of MetS and its determinant factors among type2 diabetes mellitus (T2DM) patients attending a specialized hospital.

Methods: A cross-sectional study was conducted on a total of 256 T2DM patients from the first march to 30th May 2017 at university of gondar comprehensive specialized hospital (UGCSH). Data was collected based on STROBE (strengthening the reporting of observational studies in epidemiology) statement. Bivariable and multivariable logistic regression analysis were run to identify predictors of MetS from the independent variables and significance test was set at $P<0.05$.

Results: The prevalence of MetS in this study was $70.3,57 \& 45.3 \%$ and it is more common in females $(66.1,83.3$ \& 70.7\%) by using national cholesterol education program adult treatment panel III (NCEP-ATP III), International diabetic federation (IDF) and world health organization (WHO) criteria respectively. The most prevalent components of MetS were low level of high density lipoprotein ( $\mathrm{HDL}$ ) and triglyceride(TG). By usingIDF criteria, female gender was significantly associated with MetS (AOR $=0.2$ at $95 \% \mathrm{Cl}: 0.1,0.6 P=0.00$ ). Where as by NCEP-ATP IIIcriteria, age between 51 and 64 years old $(\mathrm{AOR}=2.495 \% \mathrm{Cl}: 1.0,5.8, P=0.04)$, self employment $(\mathrm{AOR}=2.795 \% \mathrm{Cl}: 1.1,6.5, P=0$. 03), and completetion of secondary school and above ( $\mathrm{AOR}=3.2,95 \% \mathrm{Cl}: 1.6,6.7, P=0.001$ ) were predictors for the development of MetS. In the WHO criteria, being single in marital status was significantly associated with MetS ( $\mathrm{AOR}=17$ at $95 \% \mathrm{Cl}: 1.8,166, P=0.000$ ).

Conclusions: This study demonstrates that Metabolic syndrome is a major health concern for diabetic patients in Ethiopia and they are at increased risk of developing complications such as cardiovascular diseases and premature mortality. The predictors female gender, age between 51 and 64 years old, urban area residence, and being single are modifiable.Thus, health authorities shall provide targeted interventions such as life style modifications to these most at risk sub-populations of diabetic patients.
\end{abstract}

Keywords: Metabolic syndrome, Type 2 diabetes mellitus, University of Gondar, Ethiopia

\section{Background}

The burden of non-communicable disease in the developing countries is increasing, and leading to high mortality rates [1]. Nowadays T2DM is pandemic and there are no signs of reduction in the incidence rates [2]. Forexamle, according to international diabetes federation report indicates that more than 415 million of people worldwide adults have diabetes. By 2040 this will rise to

\footnotetext{
* Correspondence: mekuanentk@gmail.com

${ }^{1}$ Department of Clinical Pharmacy, School of Pharmacy, College of Medicine and Health Sciences, University of Gondar, Lideta Street, P.o.box: 196, Gondar, Ethiopia

Full list of author information is available at the end of the article
}

642 million. In Africa, 441 million people live with diabetes which is likely to increase by 926 million in 2040 [3]. Diabetic population are at increased risk of mortality and morbidity primarily due to cardiovascular diseases [4]. The relative risks are 1 to 3 in men and from 2 to 5 in women [5]. Metabolic syndrome would have its own contribution in these outcomes of DM. Metabolic syndromeis highly prevalent in T2DM patients [6-8]. However, several studies have reported lower prevalence of MetS $[9,10]$ and this is largely due to differences in characteristics of the studied population such as residence, type of disease and comorbidities, etc.

(c) The Author(s). 2018 Open Access This article is distributed under the terms of the Creative Commons Attribution 4.0 International License (http://creativecommons.org/licenses/by/4.0/), which permits unrestricted use, distribution, and 
Metabolic syndrome can be defined as a cluster of interconnected cardio-metabolic dysfunctions which is characterized by the increase in fasting blood sugar (FBS), abdominal circumference (AC), arterial pressure (AP), triglycerides (TG), and reduction in high-density lipoprotein cholesterol (HDL) [11]. This syndrome has different set of criterias to measure it. Those are National Cholesterol Education Program Adult Treatment Panel III (NCEP-ATP III) [12], WHO criteria's [13] and IDF [14]. The NCEP-ATP III definition uses the presence of 3 or more parameters as a cutoff to define MetS and the WHO as well as IDF definitions require the presence of at least two parameters.

The syndrome can directly contributes to the development of CVD and the appearance of T2DM in non-diabetic patients. Additionally, it increases the risk of premature death, renal disease, mental disorders and cancer. Thus MetS represents a serious public health problem [15-17].

Metabolic syndrome is not also with out cost implications. For instance, Boudreau et al. found that costs for subjects with diabetes plus weight risk, dyslipidemia, and hypertension were almost double the costs for subjects with prediabetes plus similar risk factors (\$8067 vs. \$4638) [18].

Globally, $20-25 \%$ of the adult population has MetS and they are twice as likely to die from it; and they are three times more likely to have a heart attack or stroke compared with people without the syndrome [14, 19]. However, the prevalence of MetS in type 2 diabetes in sub-Saharan Africans according to two sets of diagnostic criteria was $71.7 \%$ according to the IDF criteria and 60.4\% using NCEP-ATP III criteria [20]. In Ethiopia the prevalence of MetS was range from (26-70\%) using NCEP-ATP III criteria [21-23].

Nowadays, MetS has become a significant public health problem. Therefore, there is a need for investigation in this area [24]. Taking into consideration, diabetic patients who had MetS also they have cardiovascular risk factors, therefore the diagnosis of MetS in those patients is very important for detection, prevention, and treatment of the underlying risk factors and for the reduction of the cardiovascular disease burden in the general population $[25,26]$.

While limited studies of MetS among diabetic patients in Ethiopia acknowledge its burden, they followed a single criteria(NCEP-ATP III) to define MetS and using a signle criteria may either under or over estimate the problem. Thus denying or providing interventions to minimize the risks of MetS complications would be irrational since a given patient may be categorized as having MetS in one set of definition but not in the others. In this regard, the present study employed three commonly used criteria to define MetS so that it would be easy to acknowledge the importance of having a unified MetS criterion to make appropriate clinical decision in the context of Ethiopia.Therefore, this study was aimed at inevestigating the prevalence of MetS and its determinant factors among T2DM patients attending a comphrensivespecialized hospital.

\section{Methods}

\section{Study Area \& Period}

The study was conducted from March to May 2017 at UGCSH, Northwest Ethiopia. The hospital is currently serving more than 5 million people in the surrounding area andit is located in Gondar town, $750 \mathrm{~km}$ Northwest of the capital city. It has more than 400 beds and fourteen different units that provide medical services to nearly 250,000 out-patients each year. More than 5 thousand diabetic patients attend the diabetic follow up clinic.

\section{Study design and population}

An institutional based cross sectional study design was followed.The source populations were all patients attending the facility on out-patient basis at UGCSH.Whereas, all adult T2DM patients attending the facility on out-patient basis during the study period and volunteered to take part in the study were the study population. Those patients whose age $\geq 20$ years old and diagnosed as T2DM undergoing treatment with the facility were included in the study. Whereas, pregnant women, excessive alcohol or other drug abuse, having current psychiatric treatment and incomplete patient's data were excluded from the study.

\section{Sample size and sampling procedure}

The sample size was calculated based on single population proportion formula [27]. By using the following assumption: $(1.96)^{2}$ were used for $Z \frac{\alpha}{2}$ and the proportion (P) of MetS in these groups was 0.5 . With $95 \%$ confidence interval $(\mathrm{CI})$ and marginal error (d) of $5 \%$.

$$
n=\frac{Z_{\frac{\alpha}{2}} 2 P(1-P)}{d^{2}}
$$

Based on the above formula, assumptions, correction formula and $5 \%$ of contingency the sample size(n) was calculated to be 256. Study participants were selected using systematic random sampling technique. Then, every third patient arrived at the clinic was selected for the study.

\section{Data collection procedure}

Data of socio demographic and economic (age, sex, monthly income, life style, family history of diabetes and other diseases/disorders) of the study participants were 
collected by using standardized interview questioner.Whereas, data of HDL, fasting plasma glucose (FPG), and TG were recorded from patient files and chart.The components of MetS was identified and determined according to NCEP-ATP III, IDF and WHO definitions. Anthropometric data of the study participants (weight, height and waist circumference) was obtained by two data collector nurses who are working at UGCSH diabetic clinics. Weight was obtained from patients using weight balance while they were visiting the clinics during their follow-up. The average follow-up interval was 23 months. Height of the patients were assessed using meter and also data collectors were instruct participants to stand upright, motionless,and touching their thighs with their palms. Based on height and weight body mass index was calculated. Waist circumference (WC) was measured midway between the inferior angle of the ribs and the supra-iliac crest by using Meter [28]. After $10 \mathrm{~min}$ of arrival of the study participants at UGCSH diabetic clinic, Blood pressure (BP) was measured using a standard adult arm cuff of mercury type sphygmomanometer by the recruited nurses as data collectors who working in theclinic. Inorder to assure the reliability of BP measurement data collectors were taken two readings with 1 minute interval and the average of the two readings was recorded as the final $\mathrm{BP}$ of the patient. However, a third measurement was taken if the difference between the two readings was greater than $5 \mathrm{mmHg}$ and the average of the $3 \mathrm{BP}$ readings was recorded as the final BP of the patient [29].

\section{Data quality assurance}

In order to control the quality of data, pre-test was done in the data abstraction format before the main data collection on a sample equivalent to $13(5 \%)$ of the total sample size in randomly selected patients. The pretested papers were not included in the study and appropriate adjustment was done on the data abstraction format. In addition to this the principal investigator had supervised the data collectors during data collection. Thenthe collected data were checked for completeness and consistency on daily basis.

\section{Data analysis and interpretation}

The collected data were entered into Epi Info version 7 and exported to statistical package for the social sciences (SPSS) version 20 for statistical analysis. The results presented using tables and figures. Frequency distribution was calculated. The prevalence of patients with MetS was calculated, dividing the number of patients with MetS by the total number of study participants. To identify factors independently associated with the occurrence of MetS Bivariable and multivariable logistic regression analysis was run. The results of Bivariable and multivariable analysis were reported as crude and adjusted odds ratio at $95 \%$ confidence intervals $(95 \% \mathrm{CI})$ and $P$-value $\leq 0.05$ was considered as statistical significance.

\section{Operational definitions NCEP-ATP III criteria}

Study participants were classified as having MetS if they had three or more of the following risk factors: waist circumference ( $>102 \mathrm{~cm}$ for men and $>88 \mathrm{~cm}$ for women), high plasma triglycerides $(\geq 150 \mathrm{mg} / \mathrm{dl})$, low HDL cholesterol $(<40 \mathrm{mg} / \mathrm{dl}$ for men and $<50 \mathrm{mg} / \mathrm{dl}$ for women), blood pressure $(\geq 130 / 85 \mathrm{mmHg})$ and fasting plasma glucose $(\geq 110 \mathrm{mg} / \mathrm{dl})[12]$.

\section{WHO criteria}

Study participants were classified as having MetS as along with DM if they had any two of the following components: Obesity: BMI (>30 kg/m2), high serum triglycerides, $(\geq 150 \mathrm{mg} / \mathrm{dl})$, low serum high density lipoprotein cholesterol $(<35 \mathrm{mg} / \mathrm{dl}$ for men and $<$ $39 \mathrm{mg} / \mathrm{dl}$ for women) and having hypertension $(\geq 140 /$ $90 \mathrm{mmHg}$ [13].

\section{IDFcriteria}

Study participants were classified as having MetS as along with central obesity if they had any two of the following components:Raised TG levels $\geq 150 \mathrm{mg} / \mathrm{dl}$ $(1.7 \mathrm{mmol} / \mathrm{l})$, or specific treatment for this lipid abnormality, reduced HDL-cholesterol $<40 \mathrm{mg} / \mathrm{dl}(1.03 \mathrm{mmol} / \mathrm{l})$ in males and $<50 \mathrm{mg} / \mathrm{dl}(1.29 \mathrm{mmol} / \mathrm{l})$ in females, or specific treatment for this lipid abnormality, raised blood pressure: systolic BP $\geq 130$ or diastolic $\mathrm{BP} \geq 85 \mathrm{mmHg}$ or treatment of previously diagnosed hypertension, raised fasting blood glucose $\geq 100 \mathrm{mg} / \mathrm{dl}$ ( $\geq 5.6 \mathrm{mmol} / \mathrm{l})$ or previously diagnosed diabetes and waist circumference $(>94 \mathrm{cmfor}$ men and $>$ $88 \mathrm{~cm}$ for women [14].

\section{Body mass index (BMI)}

Was defined as the ratio between weight $(\mathrm{kg})$ and the square of the height $(\mathrm{m})$ and used to categorize BMI-measured weight status: patients with $(\mathrm{BMI} \leq 18.5)$ statedas under weight, patients with (BMI 18.5-24.9) consider as normal,however, patients with (BMI 25.029.9 ) is overweight and obese if BMI is $\geq 30$ [22].

\section{Results}

\section{Socio-demographic characteristics}

A total of 256 study participants were included in the study of which more than half of them were females 143 (55.9\%). The highest number of study participants were in the age group (51-64) years old. More than three fourth were 207 (80.9\%) lives in urban area and 93 (36.3\%) of them were complete their secondary school 
and above. In addition, more than two third of 219 (85\%) were married.

The total number of unemployed study participants were 131 (51.2\%) and majority of them 116 (45.3\%) had $<600$ Ethiopian birr monthly income. The highest number $(81.6 \%)$ of them used palm oil for food preparation. In addition to this, majority of study participants 136 (53.1\%) were not involved in work vigarious intensity of activity and the highest number 173 (67.6\%) of them were not did regular physical exercise. One hundred sixty seven $(62.2 \%)$ of study participants have no family history of chronic diseases. Around half of the study subjects 136 (53.1\%) diagnosed DM between 1 and 5 years duration and all of them were under medication. Most of them 132 (51.5\%) were also undertaking combination treatment. Details are presented in Table 1.

\section{Prevalence of metabolic syndrome with each criteria}

The prevalence of MetS in this study was 180 (70.3\%), 146 (57\%) and 116 (43.3\%) using NCEP(ATPIII), IDF and WHO criteria respectively (Fig. 1).

\section{Frequency of metabolic syndrome components by sex}

The frequency of MetS components in this study based on NCEP-ATP III criteria were 53.5, 68.8 and $67.2 \%$ for abdominal obesity, elevated triglyceride and reduced HDL respectively. Whereas, using the IDF criteria the prevalence was $61.7,67.6$ and $66.8 \%$ for abdominal obesity, elevated triglyceride and reduced HDL respectively. Details are presented in Table 2.

\section{Factors associated with metabolic syndrome}

In order to control confounders effect multivariable logistic regression analysis was run to analyze variables which were significantly associated to different components of MetS using different criteria in bivariable logistic analysis. These variables were sex, age, educational status, residency, duration since DM diagnosed, monthly income, family history of chronic disease and marital status. The analysis showed that, sex was significantly associated with MetS by using IDF criteria. Based on this, female patients were $(\mathrm{AOR}=0.2$ at $95 \% \mathrm{CI}$ : $0.1,0.6, P=$ $0.00)$ significantly associated with MetS compared to men using IDF criteria. Details are presented in Table 3.

Using NCEP-ATPII criteria, female sex was (AOR $=0.2$ at $95 \% \mathrm{CI}: 0.1,0.6, P=0.00)$ significantly associated with MetS compared to male sex. Similarly, patients whose age is between 51 and 64 years old were about two $(\mathrm{AOR}=2.4$ $95 \%$ CI: $1.0,5.8, P=0.04$ ) times more likely to haveMetS compared to those patients whose age is $<30$ years old. Likewise,self employed participants were about three $(\mathrm{AOR}=2.795 \% \mathrm{CI}: 1.1,6.5, P=0.03)$ times more likely to develop MetS compared to those unemployed. Patients who completed secondary school and above were about three $(\mathrm{AOR}=3.2,95 \% \mathrm{CI}: 1.6,6.7, P=0.001)$ times more likely to develop MetS compared to those unable to read and write. In addition, patients whose DM diagnosis duration was less than 1 year were about three $(\mathrm{AOR}=2.7$ $95 \% \mathrm{CI}=1.1,7.1, P=0.04)$ times more likely to develop MetS compared to those with DM diagnosis duration 1-5 years. Details are presented in Table 4.

Based onWHO criteria female sex was $(\mathrm{AOR}=0.4$ at 95\%CI: $0.2,0.7, P=0.000$ ) significantly associated with MetS compared to male sex. Patients who were single were significantly associated with MetS and were about seventeen $(\mathrm{AOR}=17$ at $95 \% \mathrm{CI}: 1.8,166, P=0.01)$ times more likely to develop MetS compared to those divorced patients.Details are presented in Table 5 .

\section{Discussion}

This study was aimed at describing the prevalence and predictors of Metabolic syndrome among type 2 diabetic patients attending a comprehensive specialized hospital in Northwest Ethiopia. The main finding of the present study demonstrates that MetS is a major health concern for diabetic patients in Ethiopia and the predictors like female gender, age between 51 and 64 years old, urban area residence, and being single, are modifiable.

The prevalence of MetS in this study was 70.3, 57 \& 45.3\% using NCEP-ATP III, IDF\& WHO criteria respectively. These different prevalence rates arise due to the different cutoff points and sets of criteria used by those three definitions. In previous studies among DM patients, a lower $45.9 \%$ and comparable $70.1 \%$ results were reported from Ethiopia using NCEP-ATP III criteria [22, 23]. However, a higher rate of prevalence, 73.9, 69.9 and $66.8 \%$, was reported from Nepal using NCEP-ATP III, WHO and IDF criteria respectively [30] and 73.4 \& $64.9 \%$ using NCEP-ATP III and IDF criteria respectively was reported from Iran [31]. On the other hand, a lower prevalence of MetS was reported from India 45.8, 57.7 and $28 \%$ using NCEP-ATP III, WHO and IDF criteria respectively [8] and 58\% was from Ghana using NCEP-ATP III criteria [7]. The prevalence of MetS in the present study some what different from others and this could be due to differences in sample size, socio-economic status, ethnicity difference [32], sampling method and difference in life style of study participants.

The present study demonstrated that prevalence of MetS was found to be higher in female $(83.3,66.1$ \& $70.7 \%)$ study participants than men (17, 31.9 \& 29.3\%) using IDF, NCEP-ATPIII \& WHO criteria's respectively. This result is in agreement with other studies [7, 30, 31]. As shown in Table 2, a significantly higher proportion of females than males have abnormal components in four (66.7\%) of the six components used to define MetS in the three criterias. This might explain the observed 
Table 1 Socio demographic characteristics of the study participants at UGCSH, June 2017

\begin{tabular}{|c|c|c|c|}
\hline Variables & & Frequency & Percentage (\%) \\
\hline \multirow[t]{2}{*}{ Sex } & Male & 113 & 44.1 \\
\hline & Female & 143 & 55.9 \\
\hline \multirow[t]{5}{*}{ Age (years) } & $\leq 30$ & 27 & 10.5 \\
\hline & $31-40$ & 15 & 5.9 \\
\hline & $41-50$ & 56 & 21.9 \\
\hline & $51-64$ & 92 & 35.9 \\
\hline & $\geq 65$ & 66 & 25.8 \\
\hline \multirow[t]{2}{*}{ Residency } & Urban & 207 & 80.9 \\
\hline & Rural & 49 & 19.1 \\
\hline \multirow[t]{3}{*}{ Educational status } & Unable to read and write & 76 & 29.7 \\
\hline & Primary school & 87 & 34 \\
\hline & Secondary school and above & 93 & 36.3 \\
\hline \multirow[t]{4}{*}{ Marital status } & Single & 18 & 7 \\
\hline & Married & 219 & 85.5 \\
\hline & Divorced & 7 & 2.7 \\
\hline & Widowed & 12 & 4.7 \\
\hline \multirow[t]{3}{*}{ Occupation } & Government & 78 & 30.5 \\
\hline & Unemployed & 131 & 51.2 \\
\hline & Self employed & 47 & 18.4 \\
\hline \multirow[t]{3}{*}{ Monthly income(ETB) } & $<600$ birr & 116 & 45.3 \\
\hline & 601-1500birr & 68 & 26.6 \\
\hline & $>1500$ birr & 72 & 28.1 \\
\hline \multirow[t]{2}{*}{ Types of Oil used } & Palm Oil & 209 & 81.9 \\
\hline & Cereal Oil & 46 & 18.9 \\
\hline \multirow{2}{*}{$\begin{array}{l}\text { Work involving vigorous } \\
\text { intensity of activity }\end{array}$} & Yes & 120 & 46.9 \\
\hline & No & 136 & 53.1 \\
\hline \multirow[t]{2}{*}{ Regular physical exercise } & Yes & 83 & 32.4 \\
\hline & No & 173 & 67.6 \\
\hline \multirow{2}{*}{$\begin{array}{l}\text { Family history of chronic } \\
\text { disease }\end{array}$} & Yes & 89 & 34.8 \\
\hline & No & 167 & 65.2 \\
\hline \multirow{3}{*}{$\begin{array}{l}\text { Duration since diabetic } \\
\text { mellitus diagnosed }\end{array}$} & $<1$ year & 22 & 8.6 \\
\hline & $1-5$ years & 136 & 53.1 \\
\hline & $>6$ years & 98 & 38.3 \\
\hline \multirow{2}{*}{$\begin{array}{l}\text { Anti diabetic medication } \\
\text { started }\end{array}$} & Yes & 256 & 100 \\
\hline & No & 0 & 0 \\
\hline \multirow{3}{*}{$\begin{array}{l}\text { Duration since anti } \\
\text { Diabetic started }\end{array}$} & $<1$ year & 24 & 9.4 \\
\hline & $1-5$ years & 135 & 52.7 \\
\hline & $>6$ years & 97 & 37.9 \\
\hline \multirow{4}{*}{$\begin{array}{l}\text { Total number of } \\
\text { medications taken }\end{array}$} & 1 & 113 & 44.1 \\
\hline & 2 & 85 & 33.2 \\
\hline & 3 & 40 & 15.6 \\
\hline & 4 & 7 & 2.7 \\
\hline
\end{tabular}




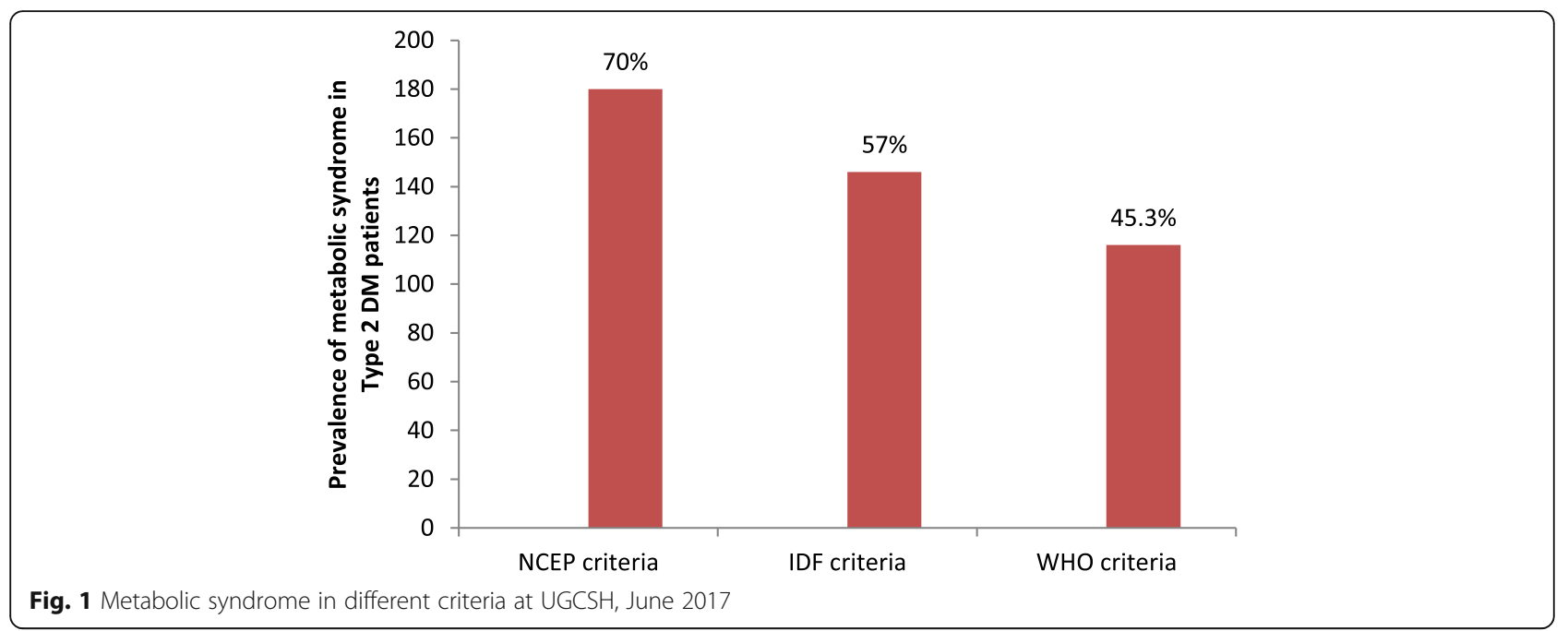

higher prevalence of MetS in the female geneder. Such discrepancy is attributed to the several physiological differences: Pregnancy induced increase in weight as well as gestational DM; the use of hormonal oral contraceptives that can decrease insulin sensitivity, glucose tolerance, increase blood pressure and increase in weight gain; menopause promotes a change in body fat distribution to increase central adiposity [33]. However, as the majority of females in the present study $(81.8 \%)$ were above 46 years old, the increased prevalence of MetS among females unlike that of males may be due to menopause. The presence of hormonal replacement therapy (HRT) was, however, not assessed but might have some effect on the higher prevalence of MetS. Inaddition, less proportion of females were involved in regular physical exercise than males in this study which might have its own contribution to the observed higher MetS prevalence among female. Females in Ethiopia are socio-economically and culturally influenced to stay at home so that they are typically involved in daily living activities rather than regular physical exercise to maintain body fitness. The role of exercise in minimizing risks of developing MetS is reported in Greec study of 1128 men and 1154 women [34].

According to the NCEP- ATPIII criteria, where the highest prevalence of MetS was observed, TG and HDL were the most frequent abnormal MetS components. Abnormal levels of TG and HDL has been implicated with adverse health effects. Fore example, Callaghan et al. reported that hypertriglyceridemia is a significant

Table 2 Frequency of metabolic syndrome components among T2DM patients with sex, at UGCSH, June 2017

\begin{tabular}{|c|c|c|c|c|c|}
\hline Metabolic components & Criteria for MetS & N (\%) & Male & Female & $P$ value \\
\hline \multirow[t]{2}{*}{ Abnormal obesity } & IDF & $42(16.4)$ & $6(5.3 \%)$ & $36(25.2 \%)$ & $<0.0001$ \\
\hline & WHO & $42(16.4)$ & $7(6.2 \%)$ & $35(24.5 \%)$ & $<0.0001$ \\
\hline \multirow[t]{2}{*}{ Abnormal fasting } & IDF & $239(93.4 \%)$ & 104 (92\%) & 135 (94.4\%) & 0.452 \\
\hline & NCEP & $236(92.2 \%)$ & 104 (92\%) & 132 (92.3\%) & 0.936 \\
\hline \multirow[t]{3}{*}{ Abnormal HDL } & IDF & $171(66.8 \%)$ & $58(51.3 \%)$ & $113(79 \%)$ & $<0.0001$ \\
\hline & WHO & $86(33.6 \%)$ & $22(19.5 \%)$ & $64(44.8 \%)$ & $<0.0001$ \\
\hline & NCEP & $172(67.2 \%)$ & $58(51.3 \%)$ & 114 (79.7\%) & $<0.0001$ \\
\hline \multirow[t]{3}{*}{ Abnormal TG } & IDF & $173(67.6 \%)$ & $65(57.5 \%)$ & 108 (75.5\%) & $<0.002$ \\
\hline & WHO & $172(67.2 \%)$ & $64(56.6 \%)$ & 108 (75.5\%) & $<0.002$ \\
\hline & NCEP & $176(68.8 \%)$ & $66(58.4 \%)$ & 110 (76.9\%) & $<0.002$ \\
\hline \multirow[t]{2}{*}{ Abnormal WC } & IDF & $158(61.7 \%)$ & 45 (39.8\%) & 113 (79.0\%) & $<0.0001$ \\
\hline & NCEP & $137(53.5 \%)$ & $24(21.2 \%)$ & $113(79.0 \%)$ & $<0.0001$ \\
\hline \multirow[t]{3}{*}{ Abnormal BP } & IDF & $110(43.0 \%)$ & $46(40.7 \%)$ & $64(44.8 \%)$ & 0.516 \\
\hline & WHO & $61(23.8 \%)$ & $26(23 \%)$ & $35(24.5 \%)$ & 0.784 \\
\hline & NCEP & $111(43.4 \%)$ & 47 (41.6\%) & $64(44.8 \%)$ & 0.612 \\
\hline
\end{tabular}


Table 3 Bivariable and multivariable logistic regression analysis by using IDF criteria at UGCSH, June 2017

\begin{tabular}{|c|c|c|c|c|c|c|c|}
\hline \multirow[t]{2}{*}{ Variable } & & \multicolumn{2}{|l|}{ Mets } & \multirow[t]{2}{*}{ COR 95\%Cl } & \multirow[t]{2}{*}{$P$-value } & \multirow[t]{2}{*}{ AOR 95\% Cl } & \multirow[t]{2}{*}{$P$-value } \\
\hline & & Yes & No & & & & \\
\hline \multirow[t]{2}{*}{ Sex } & Male & $40(27.4 \%)$ & $105(50.2 \%)$ & 1.00 & 0.00 & $0.2(0.1,0.6)$ & $<0.00^{*}$ \\
\hline & Female & $106(72.6 \%)$ & 104 (49.8\%) & $0.2(0.1,0.4)$ & & & \\
\hline \multirow[t]{5}{*}{ Age } & $<30$ & $0(0 \% 0$ & $27(100 \%)$ & 1.00 & - & & \\
\hline & $31-40$ & $2(13.3 \%)$ & $13(86.7 \%)$ & $0.0(0.0,-)$ & 0.9 & & \\
\hline & $41-50$ & $9(16.1 \%)$ & 47 (83.9\%) & $0.4(0.9,2.2)$ & 0.3 & & \\
\hline & $51-64$ & 19 (20.7\%) & $73(79.3 \%)$ & $0.5(0.2,1.4)$ & 0.2 & & \\
\hline & $>65$ & 17 (25.8\%) & 49 (74.2\%) & $0.8(0.4,1.6)$ & 0.5 & & \\
\hline \multirow[t]{2}{*}{ Residency } & Urban & 40 (19.3\%) & $167(80.7 \%)$ & $0.7(0.3,1.7)$ & 0.41 & & \\
\hline & Rural & $7(14.3 \%)$ & 42 (85.7\%) & 1.00 & - & & \\
\hline \multirow[t]{3}{*}{ Educational status } & $\begin{array}{l}\text { Unable to read } \\
\text { and write }\end{array}$ & $22(46.8 \%)$ & $54(25.8 \%)$ & $0.4(0.2,0.9)$ & 0.03 & - & - \\
\hline & Primary school & $13(27.7 \%)$ & 74 (35.4\%) & 1.00 & - & $1.3(0.7,3.6)$ & 0.2 \\
\hline & $\begin{array}{l}\text { Secondary school } \\
\text { and above }\end{array}$ & $12(25.5 \%)$ & 81 (38.8\%) & $0.4(0.2,0.8)$ & 0.01 & $1.4(0.5,3.3)$ & 0.4 \\
\hline \multirow[t]{4}{*}{ Marital status } & Single & $4(8.5 \%)$ & $14(6.7 \%)$ & $0.4(0.1,1.3)$ & 0.1 & & \\
\hline & Married & $35(74.5 \%)$ & $184(88 \%)$ & $2.7(0.4,18.1)$ & 0.3 & & \\
\hline & Divorced & $4(8.5 \%)$ & $3(1.4 \% 0$ & 1.00 & - & & \\
\hline & Widowed & $4(8.5 \%)$ & $8(3.8 \%)$ & $0.57(0.1,2.9)$ & 0.5 & & \\
\hline \multirow[t]{3}{*}{ Occupation } & Government & $13(27.7 \%)$ & 65 (31.1\%) & 1.00 & - & & \\
\hline & Unemployed & $29(61.7 \%)$ & $102(48.8 \%)$ & $0.4(0.2,1.2)$ & 0.09 & & \\
\hline & Self employed & $5(10.6 \%)$ & $42(20.1 \%)$ & $0.7(0.3,1.4)$ & 0.3 & & \\
\hline \multirow[t]{3}{*}{ Monthly income(ETB) } & $<600$ birr & $21(44.7 \%)$ & 95 (45.5\%) & 1.00 & - & & \\
\hline & 601-1500 birr & $13(27.7 \%)$ & $55(26.3 \%)$ & $1.0(0.5,2.2)$ & 0.9 & & \\
\hline & $>1501$ birr & $13(27.7 \%)$ & 59 (28.2\%) & $1.1(0.5,2.5)$ & 0.8 & & \\
\hline \multirow[t]{2}{*}{ Types of Oil used } & Palm Oil & 38 (80.9\%) & $172(82.3 \%)$ & $1.1(0.5,2.5)$ & 0.8 & & \\
\hline & Cereal Oil & $9(19.1 \%)$ & 37 (17.7\%) & 1.00 & - & & \\
\hline \multirow{2}{*}{$\begin{array}{l}\text { Work involving vigorous } \\
\text { intensity of activity }\end{array}$} & Yes & $21(44.7 \%)$ & $26(55.3 \%)$ & 1.00 & - & & \\
\hline & No & 99 (47.4\%) & $110(52.6 \%)$ & $0.9(0.5,1.7)$ & 0.7 & & \\
\hline \multirow[t]{2}{*}{ Regular physical exercise } & Yes & $13(27.7 \%)$ & $34(72.3 \%)$ & 1.00 & - & & \\
\hline & No & 70 (33.5\%) & $139(66.5 \%)$ & $0.8(0.4,1.5)$ & 0.4 & & \\
\hline \multirow{2}{*}{$\begin{array}{l}\text { Family history of chronic } \\
\text { disease }\end{array}$} & Yes & $21(44.7 \%)$ & $26(55.3 \%)$ & $0.6(0.3,1.1)$ & 0.1 & & \\
\hline & No & $68(32.5)$ & $141(67.5 \%)$ & 1.00 & - & & \\
\hline \multirow{3}{*}{$\begin{array}{l}\text { Duration since Diabetic } \\
\text { mellitus diagnosed }\end{array}$} & $<1$ Year & $4(8.5 \%)$ & $18(8.6 \%)$ & 1.00 & - & & \\
\hline & 1-5 Years & 25 (53.2\%) & $111(53.1 \%)$ & $0.9(0.5,1.5)$ & 0.9 & & \\
\hline & $>6$ Years & 18 (38.3\%) & 80 (38.3\%) & $0.9(0.3,3.1)$ & 0.9 & & \\
\hline \multirow{3}{*}{$\begin{array}{l}\text { Duration since anti } \\
\text { Diabetic started }\end{array}$} & $<1$ Year & $5(10.6 \%)$ & 19 (9.1\%) & 1.00 & - & & \\
\hline & 1-5 Years & 25 (53.2\%) & 110 (52.6\%) & $0.9(0.4,1.8)$ & 0.8 & & \\
\hline & $>6$ Years & 17 (36.2\%) & 80 (38.3\%) & $1.1(0.4,3.4)$ & 0.8 & & \\
\hline \multirow{4}{*}{$\begin{array}{l}\text { Total number of } \\
\text { medications }\end{array}$} & 1 & 94 (45.0\%) & 1.00 & - & - & & \\
\hline & 2 & $79(37.8 \%)$ & $0.8(0.16,4.1)$ & 0.8 & - & & \\
\hline & 3 & 28 (13.4\%) & $0.7(0.1,3.5)$ & 0.7 & - & & \\
\hline & 4 & 8 (3.8\%) & $1.9(0.3,9.9)$ & 1.9 & - & & \\
\hline
\end{tabular}

${ }^{*} P<0.05$ 
Table 4 Bivariable and multivariable logistic regression analysis using NCEP-ATPIII criteria at UGCSH, June 2017

\begin{tabular}{|c|c|c|c|c|c|c|c|}
\hline \multirow[t]{2}{*}{ Variable } & & \multicolumn{2}{|l|}{ Mets } & \multirow[t]{2}{*}{ COR 95\%Cl } & \multirow[t]{2}{*}{$P$-value } & \multirow[t]{2}{*}{ AOR 95\%Cl } & \multirow[t]{2}{*}{$P$-value } \\
\hline & & Yes & No & & & & \\
\hline \multirow[t]{2}{*}{ Sex } & Male & 61 (33.9\%) & $52(68.4 \%)$ & 1.00 & - & & \\
\hline & Female & $119(66.1 \%)$ & $24(31.6 \%)$ & $0.23(0.1,0.4)$ & 0.00 & $0.2(0.1,0.5)$ & $<0.00^{*}$ \\
\hline \multirow[t]{5}{*}{ Age } & $<30$ & $14(7.8 \%)$ & $13(17.1 \%)$ & 1.00 & - & & \\
\hline & $31-40$ & $9(5 \%)$ & $6(7.9 \%)$ & $0.2(0.1,0.6)$ & 0.04 & $3.8(1.4,10.9)$ & $<0.01^{*}$ \\
\hline & $41-50$ & 37 (20.6\%) & 19 (25.0\%) & $0.3(0.1,1.1)$ & 0.08 & $4.5(1.2,16.4)$ & $<0.02^{*}$ \\
\hline & $51-64$ & 66 (36.7\%) & $26(34.2 \%)$ & $0.4(0.2,0.1)$ & 0.05 & $2.4(1.0,5.8)$ & $<0.04^{*}$ \\
\hline & $>65$ & $54(30.0 \%)$ & $12(15.8 \%)$ & $0.5(0.3,1.22)$ & 0.14 & $1.9(0.9,4.4)$ & 0.1 \\
\hline \multirow[t]{2}{*}{ Residency } & Urban & $152(84.4 \%)$ & 55 (72.4\%) & $0.5(0.3,0.9)$ & 0.02 & $2.8(1.4,5.6)$ & $<0.004^{*}$ \\
\hline & Rural & $28(15.6 \%)$ & $21(27.6 \%)$ & 1.00 & - & - & - \\
\hline \multirow[t]{3}{*}{ Educational status } & $\begin{array}{l}\text { Unable to read } \\
\text { and write }\end{array}$ & $59(32.8 \%)$ & 17 (22.4\%) & $0.4(0.2,0.8)$ & 0.008 & $1.2(0.6,2.5)$ & 0.6 \\
\hline & Primary school & 67 (37.2\%) & $20(26.3 \%)$ & 1.00 & - & & \\
\hline & $\begin{array}{l}\text { Secondary school } \\
\& \text { above }\end{array}$ & $54(30,0 \%)$ & $39(51.3 \%)$ & $0.1(0.5,2.0)$ & 0.92 & $3.2(1.6,6.7)$ & $<0.001^{*}$ \\
\hline \multirow[t]{4}{*}{ Marital status } & Single & $10(5.6 \%)$ & $8(10.5 \%)$ & $0.00(0.0,-)$ & 0.9 & & \\
\hline & Married & $151(83.9 \%)$ & $68(89.5 \%)$ & $1.0(0.0,-)$ & 1.0 & & \\
\hline & Divorced & 7 (3.9\%) & $0(0.0 \%)$ & 1.00 & - & & \\
\hline & Widowed & $12(6.7 \%)$ & 0. (0.0\%) & $0.00(0.0,-)$ & 0.9 & & \\
\hline \multirow[t]{3}{*}{ Occupation } & Government & 49 (27.2\%) & $29(38.2 \%)$ & 1.00 & - & & - \\
\hline & Unemployed & $104(57.8 \%)$ & 27 (35.5\%) & $0.4(0.2-0.7)$ & 0.00 & $2.4(0.1,5.8)$ & $0.05^{*}$ \\
\hline & Self employed & $27(15.0 \%)$ & $20(26.3 \%)$ & $0.4(0.2-08)$ & 0.05 & $2.7(1.1-6.5)$ & $0.03^{*}$ \\
\hline \multirow[t]{3}{*}{ Monthly income (ETB) } & $<600$ & $90(50.0 \%)$ & $26(34.2 \%)$ & $0.5(0.3-1.0)$ & 0.06 & $1.0(0.4,2.6)$ & 0.9 \\
\hline & $601-1500$ & $44(24.4 \%)$ & $24(31.6 \%)$ & 1.00 & - & $1.2(0.6,2.6)$ & 0.6 \\
\hline & $>1501$ birr & $46(25.6 \%)$ & $26(34.2 \%)$ & $0.5(0.3-0.8)$ & 0.04 & - & - \\
\hline \multirow[t]{2}{*}{ Types of Oil used } & Palm oil & $149(82.8 \%)$ & $61(80.3 \%)$ & $0.8(0.4-1.7)$ & 0.63 & & \\
\hline & Cereal oil & $31(17.2 \%)$ & $15(19.7 \%)$ & 1.00 & - & & \\
\hline \multirow{2}{*}{$\begin{array}{l}\text { Work involving vigorous } \\
\text { intensity of activity }\end{array}$} & Yes & $78(43.3 \%)$ & $42(55.3 \%)$ & 1.00 & - & & \\
\hline & No & $102(56.7 \%)$ & $34(44.7 \%)$ & $0.6(0.4-1.1)$ & 0.08 & & \\
\hline \multirow[t]{2}{*}{ Regular physical exercise } & Yes & $57(31.7 \%)$ & $26(34.2 \%)$ & 1.00 & - & & \\
\hline & No & $123(68.3 \%)$ & $50(65.8 \%)$ & $0.9(0.5-1.6)$ & 0.7 & & \\
\hline \multirow{2}{*}{$\begin{array}{l}\text { Family history of chronic } \\
\text { disease }\end{array}$} & Yes & $68(37.8 \%)$ & $21(27.6 \%)$ & $0.6(0.3-1.1)$ & 0.12 & & \\
\hline & No & $112(62.2 \%)$ & $55(72.4 \%)$ & 1.00 & - & & \\
\hline \multirow{3}{*}{$\begin{array}{l}\text { Duration since Diabetic } \\
\text { mellitus Diagnosed }\end{array}$} & $<1$ Years & $11(6.1 \%)$ & $11(14.5 \%)$ & 1.00 & - & $2.7(1.1,7.1)$ & $0.04^{*}$ \\
\hline & $1-5$ Years & $99(55.0 \%)$ & $37(48.7 \%)$ & $0.9(0.5-1.6)$ & 0.81 & - & - \\
\hline & $>6$ Years & 70 (38.9\%) & $28(36.8 \%)$ & $0.4(0.1-1.6)$ & 0.03 & $1.1(0.6,1.9)$ & 0.8 \\
\hline \multirow{3}{*}{$\begin{array}{l}\text { Duration since anti } \\
\text { Diabetic started }\end{array}$} & $<1$ Year & $13(7.2 \%)$ & $11(14.5 \%)$ & 1.00 & - & & \\
\hline & 1-5 Year & 97 (53.9\%) & $38(50.0 \%)$ & $1.0(0.6-1.8)$ & 0.95 & & \\
\hline & $>6$ Years & 70 (38.9\%) & 27 (35.5\%) & $0.5(0.2-1.1)$ & 0.09 & & \\
\hline \multirow{4}{*}{$\begin{array}{l}\text { Total number of } \\
\text { medications }\end{array}$} & 1 & 76 (42.2\%) & 37 (48.7\%) & 1.00 & - & & \\
\hline & 2 & 70 (38.9\%) & 22 (28.9\%) & $0.5(0.1-2.5)$ & 0.4 & & \\
\hline & 3 & $26(14.4 \%)$ & 15 (19.7\%) & $0.8(0.2-4.0)$ & 0.8 & & \\
\hline & 4 & $8(4.4 \%)$ & $2(2.6 \%)$ & $0.4(0.8-2.3)$ & 0.3 & & \\
\hline
\end{tabular}


Table 5 Bivariable and multivariable logistic regression analysis result using WHO criteria at UGCSH, June 2017

\begin{tabular}{|c|c|c|c|c|c|c|c|}
\hline \multirow[t]{2}{*}{ Variable } & & \multicolumn{2}{|l|}{ Mets } & \multirow[t]{2}{*}{ COR 95\%Cl } & \multirow[t]{2}{*}{$P$ value } & \multirow[t]{2}{*}{ AOR 95\%Cl } & \multirow[t]{2}{*}{$P$-value } \\
\hline & & Yes & No & & & & \\
\hline \multirow[t]{2}{*}{ Sex } & Male & $34(29.3 \%)$ & 79 (56.4\%) & 1.00 & - & & \\
\hline & Female & $82(70.7 \%)$ & $61(43.6 \%)$ & $0.3(0.2-0.5)$ & 0.00 & $0.4(0.2,0.7)$ & $<0.000^{*}$ \\
\hline \multirow[t]{5}{*}{ Age } & $<30$ & $10(8.6 \%)$ & 17 (12.1\%) & 1.00 & - & & \\
\hline & $31-40$ & $6(5.2 \%)$ & $9(6.4 \%)$ & $0.5(0.2-1.2)$ & 0.12 & & \\
\hline & $41-50$ & $23(19.8 \%)$ & $33(23.6 \%)$ & $0.6(0.2-1.7)$ & 0.31 & & \\
\hline & $51-64$ & 41 (35.3\%) & $51(36.4 \%)$ & $0.6(0.3-1.2)$ & 0.13 & & \\
\hline & $>65$ & $36(31.0 \%)$ & $30(21.4 \%)$ & $0.7(0.4-1.3)$ & 0.21 & & \\
\hline \multirow[t]{2}{*}{ Residency } & Urban & $94(81.0 \%)$ & 113 (80.7\%) & $0.9(0.5-1.8)$ & 0.94 & & \\
\hline & Rural & $22(19.0 \%)$ & $27(19.3 \%)$ & 1.00 & - & & \\
\hline \multirow[t]{3}{*}{ Educational status } & $\begin{array}{l}\text { Unable to read } \\
\text { and write }\end{array}$ & $43(37.1 \%)$ & $33(23.6 \%)$ & $0.4(0.2-0.7)$ & 0.00 & - & - \\
\hline & Primary school & $43(37.1 \%)$ & $44(31.4 \%)$ & 1.00 & - & $0.9(0.5,1.9)$ & 0.9 \\
\hline & $\begin{array}{l}\text { Secondary school } \\
\text { and above }\end{array}$ & $30(25.9 \%)$ & $63(45.3 \%)$ & $0.8(0.4-1.4)$ & 0.4 & $1.7(0.8,3.3)$ & 0.2 \\
\hline \multirow[t]{4}{*}{ Marital status } & Single & $7(6.0 \%)$ & $11(7.9 \%)$ & $0.06(0.0-0.51)$ & 0.01 & $17(1.8166)$ & $0.01^{*}$ \\
\hline & Married & $92(79.3 \%)$ & 127 (90.7\%) & $0.5(0.02-10.3)$ & 0.7 & $14(1.8113)$ & $0.01^{*}$ \\
\hline & Divorced & $6(5.2 \%)$ & $1(0.7 \%)$ & 1.00 & - & - & - \\
\hline & Widowed & $11(9.5 \%)$ & $1(0.7 \%)$ & $0.05(0.00-0.6)$ & 0.01 & $2.0(0.1,38.8)$ & 0.6 \\
\hline \multirow[t]{3}{*}{ Occupation } & Government & $31(26.7 \%)$ & $47(33.6 \%)$ & 1.00 & - & & \\
\hline & Unemployed & 68 (58.6\%) & $63(45.0 \%)$ & $0.5(0.3-1.04)$ & 0.06 & & \\
\hline & Self employed & 17 (14.7\%) & $30(21.4 \%)$ & $0.6(0.3-1.1)$ & 0.08 & & \\
\hline \multirow[t]{3}{*}{ Monthly income (ETB) } & $<600$ birr & $56(48.3 \%)$ & $60(42.9 \%)$ & 1.00 & - & & \\
\hline & 601-1500 birr & $29(25.0 \%)$ & 39 (27.9\%) & $1.2(0.7,2.2)$ & 0.5 & & \\
\hline & $>1501$ birr & $31(26.7 \%)$ & $41(29.3 \%)$ & $0.9(0.5,1.9)$ & 0.9 & & \\
\hline \multirow[t]{2}{*}{ Types of Oil used } & Palm oil & 96 (82.8\%) & $114(81.4 \%)$ & $0.9(0.5-1.7)$ & 0.8 & & \\
\hline & Cereal oil & $20(17.2 \%)$ & $26(18.6 \%)$ & 1.00 & - & & \\
\hline \multirow{2}{*}{$\begin{array}{l}\text { Work involving } \\
\text { vigorous intensity } \\
\text { of activity }\end{array}$} & Yes & $49(42.2 \%)$ & 1 (50.7\%) & 1.00 & - & & \\
\hline & No & 67 (57.8\%) & $69(49.3 \%)$ & $0.7(0.4-1.16)$ & 0.2 & & \\
\hline \multirow{2}{*}{$\begin{array}{l}\text { Regular physical } \\
\text { exercise }\end{array}$} & Yes & $36(31.0 \%)$ & $47(33.6 \%)$ & 1.00 & - & & \\
\hline & No & $80(69.0 \%)$ & $93(66.4 \%)$ & $0.9(0.5-1.5)$ & 0.66 & & \\
\hline \multirow{2}{*}{$\begin{array}{l}\text { Family history of } \\
\text { chronic disease }\end{array}$} & Yes & $48(41.4 \%)$ & $41(29.3 \%)$ & $0.6(0.3-0.9)$ & 0.04 & $1.5(0.9,2.6)$ & 0.1 \\
\hline & No & $68(58.6 \%)$ & 99 (70.7\%) & 1.00 & - & & \\
\hline \multirow{3}{*}{$\begin{array}{l}\text { Duration since Diabetic } \\
\text { mellitus diagnosed }\end{array}$} & $<1$ Year & $11(9.5 \%)$ & $11(7.9 \%)$ & 1.00 & - & & \\
\hline & 1-5 Years & $63(54.3 \%)$ & $73(52.1 \%)$ & $0.9(0.4-2.1)$ & 0.74 & & \\
\hline & $>6$ Years & $42(36.2 \%)$ & $56(40.0 \%)$ & $0.8(0.3-1.9)$ & 0.5 & & \\
\hline \multirow{3}{*}{$\begin{array}{l}\text { Duration since anti } \\
\text { Diabetic started }\end{array}$} & $<1$ Year & $12(10.3 \%)$ & 12 (8.6\%) & 1.00 & - & & \\
\hline & 1-5 Years & $63(54.3 \%)$ & 72 (51.4\%) & $0.8(0.5-1.4)$ & 0.5 & & \\
\hline & $>6$ Years & 41 (35.3\%) & $56(40.0 \%)$ & $1.1(0.5-2.7)$ & 0.8 & & \\
\hline \multirow{4}{*}{$\begin{array}{l}\text { Total number of } \\
\text { medications }\end{array}$} & 1 & 45 (38.8\%) & 68 (48.6\%) & 1.00 & - & & \\
\hline & 2 & $47(40.5 \%)$ & 45 (32.1\%) & $0.9(0.3-3.7)$ & 0.99 & & \\
\hline & 3 & 20 (17.2\%) & $21(15.0 \%)$ & $1.6(0.4-5.9)$ & 0.50 & & \\
\hline & 4 & $4(3.4 \%)$ & $6(4.3 \%)$ & $1.4(0.4-5.8)$ & 0.61 & & \\
\hline
\end{tabular}


risk factor for lower-extremity amputation in a 10-year cohort study (from 1995 to 2006) of 28,701 diabetic patients [35]. A 2 years of multi-ethnic study of atherosclerosis on a total of 6814 participants showed that low level of HDL in the body is associated with an increased risk of CVD, coronary heart diseases and death [36]. Thus, interventions focusing on abnormal TG and HDL need to be prioritized.

Regarding to residency, the association of MetS and urbanization could be as a result of a sedentary life style, increased intake of calorie rich foods and central obesity.This result is supported by other studies world wide $[37,38]$. In addition, people who were self employed had significant association with MetS and the reason could be also sedentary life style related with the type of job they are involved.

On the other hand, patients who were secondary school and above had significantly associated with MetS.This might be due to significantly higher economic status (greater than 1500 ETB) of those who are highly educated in our study population (Secondary school and above:59 (77.6\%); primary school:15 (19.7\%). This finding is consistent with that of Chakraborty et al. and Khanam et al. [39, 40]. Therefore, higher levl of education may indirectly lead to risky life style adoption interms of dietary pattern and physical activity.

When compared to those patients aged 30 years and less, the ones in the age intervals 31-40, 41-50, and 51-64 were at inceased risk of MetS. The reasons for a direct relations of age and MetS is that age related processes such as gradual decrease in the basal metabolic rate, stress induced hypercortisolism, hypogonadism, decreased growth hormone secretion, concomitant insulin resistance and abdominal fat deposition [41, 42]. However, those patients who are 65 years old and above were found to have no significantly increased risk of MetS. This might be because of reduced survival of patients who developed MetS in this age group. In this regard, further prospective studies need to be carried out. The finding reiterates that of Devers et al. According to this study which was conducted among 1429 adults aged $\geq 25$ years from randomly selected house holds in Australia, MetS components cluster most markedly in those aged $<65$ years [43]. Therefore, serious preventive and control measures should be taken as age increases. Individuals should be advised to make life style changes. Doing reguar exercise, eating foods containing little amount of saturated fats and cholesterol as well as taking more fiber-rich foods should be encouraged. Chandalia et al. have shown that taking high fiber diets have the potential to lower fasting plasma glucose, total cholesterol, triglyceride, and helps to have good glycemic index through a decrease in gastrointestinal absorption of cholesterol and carbohydrates [44].

Regarding to duration of period since DM was diagnosed, those patients diagnosed within a year had significantly higher risk of developing MetS according to NCEP-ATPIII criteria. Since lifestyle modifications on diet and physical activity are the main initial interventions in T2DM patients, those respondents treated for short period of time may not effectively adopt the needed life style changes and hence are at increaed risk of MetS. It is also worth to note that some of the patients in our study might be in the very ealy stages of treatment so that reduction of MetS components might be unlikely. Incontrast to our finding, a previous study in Ethiopia reported the absence of impact of duration of treatment on MetS development [22]. Since in this study patients were classified based on higher cut off treatment duration i.e. below or above 10 years, it might fail to signify the impact of duration on MetS. On the otherhand, patients who stayed on treatment for short duration were not specifically isolated and compared with others who stayed longer on therapy. In this study using WHO criteria it indicate that patients who were single had association with MetS,the possible reason may be small sample size of this segment of respondants $(N=18,7 \%)$.

In general, the findings of the present stydy taken together showed that MetS is a mjor burden among T2DM patients in Ethiopia. Early identification of MetS among T2DM patients is of great importance since MetS imply increased risk of morbidities such as CVD,decreased quality of life, increased health care cost, as well as mortality. Therefore, UGCSH has to strengthen appropriate and targeted prevention strategies such as encouraging people to adopt dietary modification and physical activity which are reported to reduce occurrence and progression of MetS [45]. Inaddition, there should be a more frequent screening of patients for MetS components prior to full blow development of MetS.

This study for the first time in Ethiopia, employed three defining criteria for MetS and was able to highlight the importance of having unified definition to diagnose and make clinical decisions in the context of low income settings. Data were also collected prospectively and this strengthens the conclusions made. Yet, there are limitations and one should consider these in interpreting the findings. The study may not be generalized to the nation as a whole due to small sample size and thus further studies would be important. It is also important to show the health related outcome and economic consequences of MetS among T2DM patients in Ethiopia. 


\section{Conclusions}

In conclusion, this study demonstrates that MetS is a major health concern for diabetic patients in Ethiopia. They are at increased risk of developing complications such as cardiovascular diseases and premature mortality.The predictors, female gender, age between 51 and 64 years old, urban area residence, and being single, are modifiable. Thus, health authorities shall provide targeted interventions to this most at risk sub populations of diabetic patients such as promotion of life style modifications.

\section{Abbreviations}

CVD: Cardiovascular Diseases; DM: Diabetes Mellitus; MetS: Metabolic Syndrome; UGCSH: University of Gondar Comprehensive Specialized Hospital

\section{Acknowledgements}

The authrs appreciate the data collectors as well as the study participants.

\section{Availability of data and materials}

The data sets used and/or analysed during the current study are available from the corresponding author on reasonable request.

\section{Authors' contributions}

MKB designed the study. Both authors conducted the study, analyzed data, developed and approved the final version of the manuscript.

\section{Ethics approval and consent to participate}

Letter of ethical clearance was obtained from Ethical Review Committee of School of Pharmacy, College of Medicine and Health Sciences University of Gondar, as well as medical director of University of Gondar hospital. Informed verbal consent was obtained from each study participant with respect to their willingness to take part in the study after explaining the objective of the study. This was approved by the Ethical Review Committee of School of Pharmacy, College of Medicine and Health Sciences University of Gondar, as well as medical director of UGCSH.

\section{Consent for publication}

Not applicable.

\section{Competing interests}

The authors declare that they have no competing interests.

\section{Publisher's Note}

Springer Nature remains neutral with regard to jurisdictional claims in published maps and institutional affiliations.

\section{Author details \\ ${ }^{1}$ Department of Clinical Pharmacy, School of Pharmacy,College of Medicine and Health Sciences, University of Gondar, Lideta Street, P.o.box: 196, Gondar, Ethiopia. ²Department of Pharmacology, School of Pharmacy,College} of Medicine and Health Sciences, University of Gondar, Gondar, Ethiopia.

\section{Received: 8 January 2018 Accepted: 3 July 2018}

\section{Published online: 17 July 2018}

\section{References}

1. Islam SMS, Purnat TD, Phuong NTA, Mwingira U, Schacht K, Fröschl G. Noncommunicable diseases (NCDs) in developing countries: a symposium report. Glob Health. 2014;10(81)

2. Nijpels, Giel. Epidemiology of type 2 diabetes. 2016 Nov 23; Diapedia 3104287123 rev. no. 18. Acess on june 2017 Available from: https://doi.org/ 10.14496/dia.3104287123.18. Accessed 4 June 2017.

3. International Diabetes Federation: IDF Atlas 7th edition, 2015. Accessed on June 2017 Avilable at https://www.idf.org/e-library/epidemiology-research/ diabetes-atlas/13-diabetes-atlas-seventh-edition.html
4. Matheus AS, Tannus LR, Cobas RA, Palma CC, Negrato CA, Gomes MB. Impact of diabetes on cardiovascular disease: an update. Int J Hypertens. 2013;653789

5. Rivellese AA, Riccardi G, Vaccaro O. Cardiovascular risk in women with diabetes. Nutr Metab Cardiovasc Dis. 2010;20(6):474-80.

6. Basol G, Barutcuoglu B, Cakir Y, Ozmen B, Parildar Z, Kose T, et al. Diagnosing metabolic syndrome in type 2 diabetic Turkish patients: comparison of AHA/NHLBI and IDF definitions. Bratisl Lek Listy. 2011; $112 \cdot 253-9$

7. Nsiah K, Shang VO, Boateng KA, Mensah F. Prevalence of metabolic syndrome in type 2 diabetes mellitus patients. Int J Appl Basic Med Res. 2015;5(2):133-8.

8. Yadav D, Mahajan S, Subramanian SK, Bisen PS, Chung CH, Prasad G. Prevalence of metabolic syndrome in type 2 diabetes mellitus using NCEP-ATPIII, IDF and WHO definition and its agreement in Gwalior Chambal region of Central India. Glob J Health Sci. 2013;5(6):142-55.

9. Saloojee S, Burns JK, Motala AA. Very low rates of screening for metabolic syndrome among patients with severe mental illness in Durban, South Africa. BMC Psychiatry. 2014;14:228.

10. Morimoto A, Nishimura R, Suzuki N, Matsudaira T, Taki K, Tsujino D, et al. Low prevalence of metabolic syndrome and its components in rural Japan. Tohoku J Exp Med. 2008;216(1):69-75.

11. Alberti KG, Zimmet P, Shaw J. IDF epidemiology task force consensus group. The metabolic syndrome new worldwide definition. Lancet. 2005; 366:1059-62.

12. Executive Summary of the Third Report Of The National Cholesterol Education Program (NCEP). Expert panel on detection, evaluation, and treatment of high blood cholesterol in adults (adult treatment panel III). JAMA. 2001;285:2486-97.

13. Alberti KG, Zimmet PZ. Definition, diagnosis and classification of diabetes mellitus and its complications. Part 1: diagnosis and classification of diabetes mellitus provisional report of a WHO consultation. Diabet Med. 1998;15:539-53.

14. The IDF consensus worldwide definition of the metabolic syndrome. [Last accessed on June 2017]. Available at https://www.idf.org/e-library/ consensus-statements/60-idfconsensus-worldwide-definitionof-themetabolic-syndrome.html

15. Borena W, Edlinger $M$, Bjørge $T$, et al. A prospective study on metabolic risk factors and gallbladder cancer in the metabolic syndrome and cancer (mecan) collaborative study. PLoS One. 2014;9(2):e89368.

16. Pan A, Keum N, Okereke Ol, et al. Bidirectional association between depression and metabolic syndrome: a systematic review and meta-analysis of epidemiological studies. Diabetes Care. 2012;35(5):1171-80.

17. Thomas G, Sehgal AR, Kashyap SR, Srinivas TR, Kirwan JP, Navaneethan SD Metabolic syndrome and kidney disease: a systematic review and metaanalysis. Clin J Am Soc Nephrol. 2011;6(10):2364-73.

18. Boudreau DM, Malone DC, Raebel MA, Fishman PA, Nichols GA, Feldstein AC, et al. Health care utilization and costs by metabolic syndrome risk factors. Metab Syndr Relat Disord. 2009:7(4):305-14

19. World Health Organization (WHO): Non-Communicable Diseases Country Profile. 2011.

20. Kengne AP, Limen SN, Sobngwi E, Djouogo CF, Nouedoui C. Metabolic syndrome in type 2 diabetes: comparative prevalence according to two sets of diagnostic criteria in sub-Saharan Africans. Diabetol Metab Syndr. 2012:4:22.

21. Abda E, Hamza L, Tessema F, Cheneke W. Metabolic syndrome and associated factors among outpatients of Jimma University teaching hospital. Diabetes Metab Syndr Obes. 2016;9:47-53.

22. Woyesa SB, Hirigo AT, Wube TB. Hyperuricemia and metabolic syndrome in type 2 diabetes mellitus patients at Hawassa university comprehensive specialized hospital, south West Ethiopia. BMC Endocr Disord. 2017;17:76.

23. Tadewos A, Ambachew H, Assegu D. Pattern of metabolic syndrome in relation to gender among type-II DM patients in Hawassa university comprehensive specialized hospital, Hawassa, southern Ethiopia. Health Sci J. $2017 ; 11(3)$

24. Smith SR. Importance of diagnosing and treating the metabolic syndrome in reducing cardiovascular risk. Obesity (Silver Spring). 2006;3:128S-34S.

25. Galassi A, Reynolds K, He J. Metabolic syndrome and risk of cardiovascular disease: a meta-analysis. Am J Med. 2006;119(10):812-9.

26. Han TS, Lean ME. A clinical perspective of obesity, metabolic syndrome and cardiovascular disease. JRSM Cardiovasc Dis. 2016;5:2048004016633371. 
27. Pourhoseingholi MA, Vahedi M, Rahimzadeh M. Sample size calculation in medical studies. Gastroenterol Hepatol Bed Bench. 2013;6(1):14-7.

28. Bray GA. Obesity: Basic consideration and clinical approaches. Dis Mon. 1989:35(7):449-537.

29. Lemogoum D, Seedat YK, Mabadeje AF, Mendis S, Bovet P, Onwubere B, et al. Recommendations for prevention, diagnosis and management of hypertension and cardiovascular risk factors in sub-Saharan Africa. J Hypertens. 2003;21(11):1993-2000.

30. Pokharel DR, Khadka D, Sigdel M, et al. Prevalence of metabolic syndrome in Nepalese type 2 diabetic patients according to WHO, NCEP-ATP III, IDF and harmonized criteria. J Diabetes Metab Disord. 2014;13:104.

31. Foroozanfar Z, Najafipour $H$, Khanjani N, Bahrampour A, Ebrahimi H. The prevalence of metabolic syndrome according to different criteria and its associated factors in type 2 diabetic patients in Kerman, Iran. Iran J Med Sci. 2015:40(6):522-5.

32. Rampal S, Mahadeva S, Guallar E, Bulgiba A, Mohamed R, Rahmat R, et al. Ethnic differences in the prevalence of metabolic syndrome: results from a multi-ethnic population-based survey in Malaysia. PLoS One. 2012;7(9):e46365.

33. Bentley-Lewis R, Koruda K, Seely EW. The metabolic syndrome in women. Nat Clin Pract Endocrinol Metab. 2007;3(10):696-704.

34. Panagiotakos DB, Pitsavos CH, Chrysohoou C, Skoumas J, Tousoulis D, Toutouza M, Toutouzas PK, Stefanadis C. The Impact of lifestyle habits on the prevalence of the metabolic syndrome among Greek adults from the ATTICA study. Am Heart J. 2004;147:106-12.

35. Callaghan BC, Feldman E, Liu J, et al. Triglycerides and amputation risk in patients with diabetes: ten-year follow-up in the DISTANCE study. Diabetes Care. 2011;34(3):635-40. https://doi.org/10.2337/dc10-0878.

36. Ahmed HM, Miller M, Nasir K, McEvoy JW, Herrington D, Blumenthal RS, Blaha MJ. Primary low level of high-density lipoprotein cholesterol and risks of coronary heart disease, cardiovascular disease, and death: results from the multi-ethnic study of atherosclerosis. Am J Epidemiol. 2016; 183(10):875-83.

37. Bouguerra R, Ben Selam L, Alberti H, Ben Rayana C, El Atti J, Blouza S, et al. Prevalence of metabolic abnormalities in the Tunisian adults: a population based study. Diabete Metab. 2006;32(3):215-21.

38. Chowdhury MZI, Anik AM, Farhana Z, et al. Prevalence of metabolic syndrome in Bangladesh: a systematic review and meta-analysis of the studies. BMC Public Health. 2018;18:308.

39. Chakraborty SN, Roy SK, Rahaman MA. Epidemiological predictors of metabolic syndrome in urban West Bengal, India. J Family Med Prim Care. 2015;4(4):535-8.

40. Khanam MA, Qiu C, Lindeboom W, Streatfield PK, Kabir ZN, Wahlin Å. The metabolic syndrome: prevalence, associated factors, and impact on survival among older persons in rural Bangladesh. PLoS One. 2011;6(6):e20259.

41. Chrousos GP, Gold PW. The concepts of stress and stress system disorders. Overview of physical and behavioral homeostasis. JAMA. 1992;267:1244-52.

42. Charmandari E, Tsigos C, Chrousos G. Endocrinology of the stress response. Annu Rev Physiol. 2005;67:259-84.

43. Devers MC, Campbell S, Simmons D. Influence of age on the prevalence and components of the metabolic syndrome and the association with cardiovascular disease. BMJ Open Diabetes Res Care. 2016;4(1):e000195.

44. Chandalia M, Garg A, Lutjohann D, Bergmann VK, Grundy MS, Brinkley JL. Beneficial effects of high dietary fiber intake in patients with type 2 diabetes mellitus. N Engl J Med. 2000;342(19):1392-8.

45. Pitsavos C, Panagiotakos D, Weinem M, Stefanadis C. Diet, exercise and the metabolic syndrome. Rev Diabet Stud. 2006;3(3):118-26.

\section{Ready to submit your research? Choose BMC and benefit from:}

- fast, convenient online submission

- thorough peer review by experienced researchers in your field

- rapid publication on acceptance

- support for research data, including large and complex data types

- gold Open Access which fosters wider collaboration and increased citations

- maximum visibility for your research: over $100 \mathrm{M}$ website views per year

At BMC, research is always in progress.

Learn more biomedcentral.com/submissions 